\title{
Agglutination Enhancing Effect of Semen on Pre-Treated Erythrocyte Rhesus D Agglutinogen in Human
}

\author{
SABO, Ahmed Mohammed ${ }^{1} \quad$ GALAM, Nanyak Zingfa ${ }^{1}$ JIBRIN, Yusuf Bara ${ }^{2}$ \\ MSHELIA, Paul Philemon ${ }^{3}$ \\ 1. Department of Human Physiology, Faculty of basic Medical Sciences, College of Health Sciences, University \\ of Jos \\ 2. Department of Medicine, College of Medical Sciences, Abubakar Tafawa Balewa University Teaching \\ Hospital, Bauchi \\ 3. Department of Human Physiology, College of Medical Sciences, Abubakar Tafawa Balewa University, \\ Bauchi
}

\begin{abstract}
Human semen serves as fluids medium in which sperm cells are dispersed and swim within. Semen contains about $90 \%$ water along with proteins that include Immunoglobulin-A $\left(\mathrm{Ig}_{\mathrm{g}} \mathrm{A}\right)$, Haptoglobin, fructose sugar, other dissolved substances and electrolyte. Apart from preserving the sperm cells, semen may carry certain immunological feature as part of its protective functions. From a male partner in coital activity, semen's cellular component and proteins deposited into the vagina do not antigenically qualify as 'self'. This is a study to determine a possible agglutination resistant effect of semen on various types of $\mathrm{ABO}$ and Rhesus blood group members or agglutination enhancing effect of the same $\mathrm{ABO}$ and Rhesus group members.
\end{abstract}

Keywords: Rhesus, ABO, Blood Group Agglutination Semen Haptoglobin.

DOI: $10.7176 / \mathrm{JMPB} / 71-01$

Publication date:June $30^{\text {th }} 2021$

\section{INTRODUCTION}

A prospective mother's ovum carries antigens some of which are similar to that of the sperm cell from a destined biological father and others so different and this constitutes a lot of immunological challenges. A haploid sperm cell with either $22 \mathrm{x}$ or $22 \mathrm{y}$ chromosomal configuration ends up fertilizing the $22 \mathrm{x}$ ovum. The newly formed zygote is a new $44 \mathrm{xx}$ or $44 \mathrm{yy}$ entity. The whole journey of this sequence of events means hurdles right from the destruction of many of the sperm cells by the hostile acidic $\mathrm{pH}$ of the vaginal secretion to the curious interaction with the vaginal flora nay lactobacilli. In the course of biological evolution, nature must have successfully evaded these challenges. The acidic vaginal medium can be reduced through neutralization reaction by the alkaline nature of the semen as well as possible agglutination resistance between agglutinin(s) in vaginal secretion and agglutinogens from semen component(s). On the contrary, enhance agglutination by semen may serve as protein based augmented affinity that promotes attraction of ovum to sperm and working of antibodies to enhance opsonization and the improvement in immune reaction along the reproductive tract.

\section{MATERIAL AND METHOD}

Forty test tubes, , Glass slides, Anti Sera A, B, AB and Anti Sera D, Microscope, Capillary tubes, freshly obtained semen sample, pipette. Room temperature thermometer to measure which temperature the experiment is conducted here in the laboratory which is $26-28^{\circ} \mathrm{C}$ (comfortable cool) of the Jos city, Plateau state Nigeria. Anti Sera from Biotect Laboratory were purchased to be the source of the various agglutinins,

Forty test tubes were obtained for the work twenty of which are for the test group where where $0.5 \mathrm{ml}$ of semen is incubated with $0.5 \mathrm{ml}$ of various blood Rhesus +ve types of $\mathrm{ABO}$ system, while the other 20 are for the control group where no semen is added. All the blood sampled were earlier treated and washed with normal saline to remove the plasma. A freshly obtained semen sample from a blood group donor is obtained. Forty units of test tubes were made available and grouped into 2 for control and test series. Replicates of five were made available. Twenty mililitres of blood is obtained from each of the different donors with blood group $\mathrm{A}+, \mathrm{B}+$, $\mathrm{AB}+$ and $\mathrm{O}+$ and washed with normal saline as the source for the agglutinogens while the corresponding Anti Sera from Biotect Laboratory were purchased to be the source of the various agglutinins. Agglutinin reaction is observed with both the unaided eye and under microscopy as formation of clump of particles. 


\section{RESULT}

TABLE 1

TABLE OF DIFFERENT AGGLUTINATION REACTION TIME IN MINUTES BETWEEN AGGLUTINOGENS AND CORRESPONDING AGGLUTININS OF ABO BLOOD GROUP SPECIMENS NOT-INCUBATED WITH SEMEN AND TESTED AT ROOM TEMPERATURE

\begin{tabular}{lllll}
\hline \multicolumn{5}{c}{ Agglutination Time (Minutes) } \\
& $\mathrm{A}+$ & $\mathrm{B}+$ & $\mathrm{AB}+$ & \\
& & 1.9 & 1.2 & \\
\hline Replicate 1 & 2.3 & 1.8 & 1.0 & \\
Replicate 2 & 1.6 & 2.2 & 1.5 & \\
Replicate 3 & 1.2 & 1.6 & 1.7 & \\
Replicate 4 & 1.6 & 2.4 & 2.3 & Mean $=1.72$ \\
Replicate 5 & 1.5 & 1.98 & 1.54 &
\end{tabular}

There is no significant difference, $\mathrm{P}>0.05$, in agglutination time between different $\mathrm{ABO}$ blood group types both the non-incubated and semen pre-incubated specimens

TABLE 2

TABLE OF DIFFERENT AGGLUTINATION REACTION TIME IN MINUTES BETWEEN AGGLUTINOGENS AND CORRESPONDING AGGLUTININS OF ABO BLOOD GROUP SPECIMENS PRE-INCUBATED AND TESTED AT ROOM TEMPERATURE WITH SEMEN FROM BLOOD GROUP OVE DONOR

\begin{tabular}{lllllll}
\hline \multicolumn{2}{c}{ Agglutination Time (minutes) } & & & \\
& $\mathrm{A}+$ & $\mathrm{B}+$ & $\mathrm{AB}+$ & $\mathrm{O}+$ & & \\
\hline Replicate 1 & 2.4 & 2.3 & 2.2 & 1.1 & \\
Replicate 2 & 1.0 & 2.4 & 2.4 & 1.0 & \\
Replicate 3 & 1.1 & 1.4 & 2.3 & 2.4 & \\
Replicate 4 & 2.3 & 1.9 & 1.5 & 2.4 & \\
Replicate 5 & 2.1 & 1.8 & 1.4 & 1.0 & Mean $=1.76$ \\
\hline Mean Time & 1.78 & 1.96 & 1.96 & 1.58 & In minutes
\end{tabular}

There is no significant difference, $\mathrm{P}>0.05$, in agglutination time between different $\mathrm{ABO}$ blood group types both the non-incubated and semen pre-incubated specimens

TABLE 3

TABLE SHOWING DIFFERENTS AGGLUTINATION REACTION TIME IN MINUTES AT ROOM TEMPERATURE BETWEEN AGGLUTININ D OF THE RHESUS SYSTEM OF BLOOD GROUPING AND AGGLUTINOGEN D IN RHESUS POSITIVE TYPES OF ABO BLOOD GROUP NOT-INCUBATED WITH SEMEN

\begin{tabular}{|c|c|c|c|c|c|}
\hline & \multicolumn{4}{|c|}{ Agglutination Time (minutes) } & \\
\hline & $\mathrm{A}+\quad \mathrm{B}+$ & $\mathrm{AB}+$ & $\mathrm{O}+$ & & \\
\hline Replicate $1(\mathrm{~A}+)$ & 7.5 & 7.2 & 7.4 & 7.5 & \\
\hline Replicate $1(\mathrm{~B}+)$ & 6.6 & 7.7 & 8.8 & 8.3 & \\
\hline Replicate $1(\mathrm{AB}+)$ & 7.4 & 8.8 & 6.7 & 8.6 & \\
\hline Replicate $1(\mathrm{O}+)$ & 6.6 & 6.5 & 8.4 & 7.9 & \\
\hline Replicate 5 & 8.7 & 7.3 & 6.4 & 7.6 & \\
\hline Mean & 7.36 & 7.5 & 7.54 & 7.98 & $\begin{array}{c}\text { Mean }=7.59 \\
\text { Minutes }\end{array}$ \\
\hline
\end{tabular}


TABLE 4

TABLE SHOWING DIFFERENT AGGLUTINATION REACTION TIME IN MINUTES AT ROOM TEMPERATURE BETWEEN AGGLUTININ D OF THE RHESUS SYSTEM OF BLOOD GROUPING AND AGGLUTINOGEN D IN RHESUS POSITIVE TYPES OF ABO BLOOD GROUP PRE-INCUBATED FOR AN HOUR WITH SEMEN FROM O-VE DONOR
Agglutination Time (minutes)
$\begin{array}{llll}\mathrm{A}+ & \mathrm{B}+ & \mathrm{AB}+ & \mathrm{D}+\end{array}$

\begin{tabular}{llllll}
\hline Replicate 1 & 2.1 & 1.6 & 1.0 & 2.4 & \\
Replicate 2 & 2.2 & 1.0 & 1.3 & 1.0 & \\
Replicate 3 & 2.1 & 1.3 & 2.1 & 2.0 & \\
Replicate 4 & 2.3 & 1.5 & 1.0 & 1.1 & \\
Replicate 5 & 1.6 & 2.1 & 2.1 & 1.0 & Mean =2.02 \\
\hline Mean & 2.44 & 1.88 & 1.78 & 1.98 & Minutes
\end{tabular}

There is significant difference in agglutination reaction time between agglutinogen $\mathrm{D}$ and agglutinin $\mathrm{D}, \mathrm{P}<0.05$, where the time is shortened by the pre-incubation of the blood sample with semen.

TABLE 5

TABLE OF MEAN AGGLUTINATION REACTION TIME IN MINUTES BETWEEN VARIOUS AGGLUTINOGENS OF ABO SYSTEM WITHOUT PRE-INCUBATION WITH SEMEN

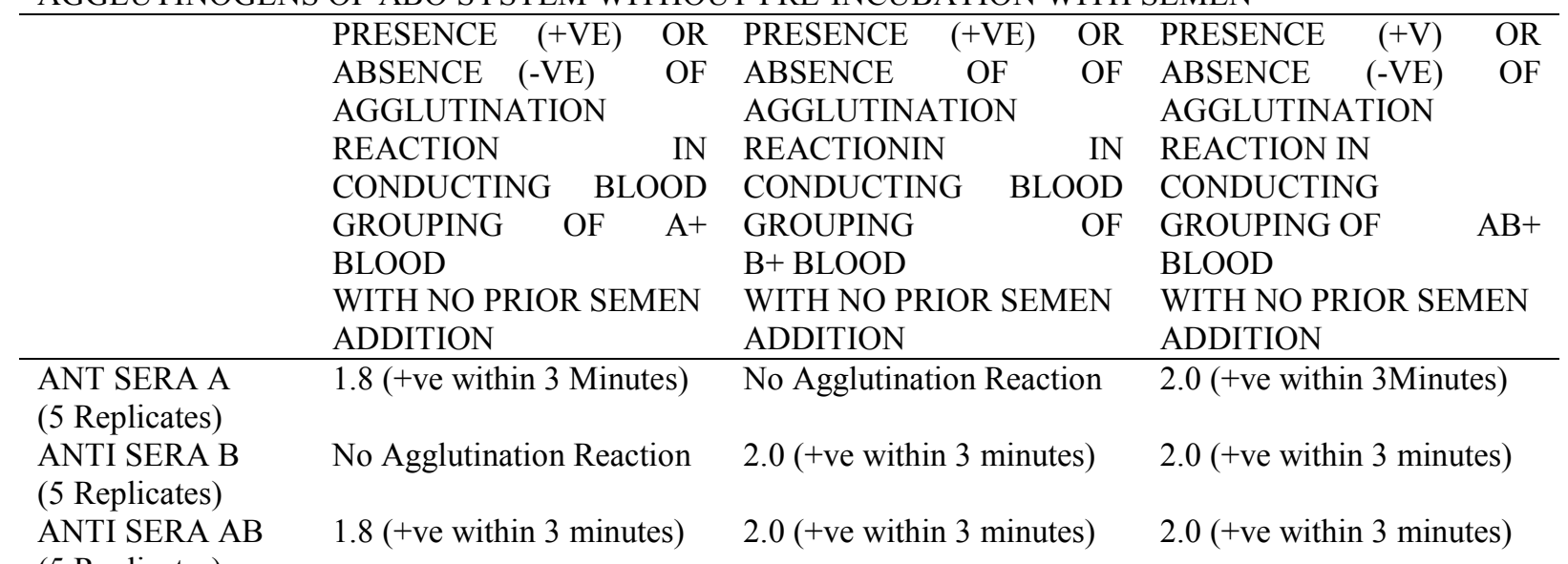

(5 Replicates)

Significant reduction in agglutination time $(\mathrm{P}<0.001)$ in response to pre-incubation with semen for an hour.

TABLE 6

TABLE OF MEAN AGGLUTINATION REACTION TIME BETWEEN VARIOUS AGGLUTINOGENS OF ABO SYSTEM PRE-INCUBATED FOR AN HOUR WITH SEMEN FROM BLOOD GROUP O-VE INDIVIDUAL

\begin{tabular}{|c|c|c|c|}
\hline & $\begin{array}{lll}\text { PRESENCE } & (+\mathrm{VE}) & \text { OR } \\
\text { ABSENCE } & (-\mathrm{VE}) & \text { OF }\end{array}$ & $\begin{array}{lll}\text { PRESENCE } & (+\mathrm{VE}) & \text { OR } \\
\text { ABSENCE } & (-\mathrm{VE}) & \text { OF }\end{array}$ & $\begin{array}{lrl}\text { PRESENCE } & (+\mathrm{V}) & \text { OR } \\
\text { ABSENCE } & (-\mathrm{VE}) & \text { OF }\end{array}$ \\
\hline & AGGLUTINATION & AGGLUTINATION & AGGLUTINATION \\
\hline & REACTION & REACTION & REACTION IN \\
\hline & CONDUCTING & CONDUCTING BLOOD & CONDUCTING \\
\hline & GROUPING $\quad$ OF $\quad \mathrm{A}+$ & GROUPING & GROUPING OF \\
\hline & BLOOD INCUBATED & B+ BLOOD INCUBATED & $\mathrm{AB}+\mathrm{BLOOD}$ \\
\hline & WITH SEMEN WITH & $\begin{array}{llll}\text { WITH } & \text { SEMEN } & \text { FOR } & 1\end{array}$ & INCUBATED WITH \\
\hline & SEMEN FOR 1 HOUR & HOUR & SEMEN FOR 1 HOUR \\
\hline $\begin{array}{l}\text { ANT SERA A } \\
\text { (5 Replicate) }\end{array}$ & 1.6 (+ve within 3 minutes) & No Agglutination Reaction & 1.5 (+ve within 3 minutes) \\
\hline $\begin{array}{l}\text { ANTI SERA B } \\
\text { (5 Replicate) }\end{array}$ & No Agglutination Reaction & 2.0 (+ve within 3 minutes) & 1.5 (+ve within 3 minutes) \\
\hline $\begin{array}{l}\text { ANTI SERA AB } \\
\text { (5 Replicate) }\end{array}$ & 1.5 (+ve within 3 minutes) & 2.0 (+ve within 3 minutes) & 1.5 (+ve within 3 minutes) \\
\hline
\end{tabular}




\section{DISCUSSION}

It has been recognized by the biomedical scientists that addition of proteins like albumin enhances antigenantibody reactions. This inform the basis of the use of albumin in Coomb's test to enhance antigen antibody reaction for detection of atypical antibodies in other blood other blood grouping systems e.g Kidd's, Kell's and Duffy's. The reactions of agglutinogens of the ABO and Rhesus systems are clearly a celebration of such a phenomenon.

The result in this work shows a highly significant $(\mathrm{P}<0.001)$ enhancement by semen of the reaction between agglutinogens of the various blood ABO blood group types used for the experiment and the Anti Sera D sera (Rhesus agglutinin). .

Haptoglobin present in the semen among other places, has previously been found in larger than usual quantity in the semen of ram during mating season. How this affect fertility is not yet ascertained. A crude sample of semen in this work has been found to enhance the reaction between antigen (Rhesus D agglutinogen) and the corresponding antibodies (Rhesus D agglutinin) but not the ABO agglutinogens and the corresponding agglutinins, and this is a pointer to a possible complex interactions. More work is needed to verify the factor(s) in the semen responsible for this finding and may lead to postulation of the role of the finding of this phenomenon in reproductive biology. A possible mechanism of action of this enhancement may be in the offing after more work.

\section{CONCLUSION}

Semen component(s) reduces the agglutination reaction time at room temperature between Rhesus agglutinogen and the corresponding Rhesus agglutinin $\mathrm{D}$ in highly significant manner, $\mathrm{P}<0.001$. This agglutination reaction enhancement does not occur at significant level, $\mathrm{P}>0.05$, with the $\mathrm{ABO}$ system of blood grouping.

\section{REFERENCES}

1. Dhaffer M. Aziz et al (2003). Detection of Haptoglobin in Seminal Plasma of Awassi Rams and the Relation With its Level in Serum and Some Parameters. J adv Res. Nov

2. Karl Landsteiner, Alexender S. Weiner (1941). Studies On an Agglutinogen (Rh) In Blood Reacting with Anti-Rhesus Sera And With Human IsoAntibodies. J Exp Med. 74(4): 309-320. Doi:10.1084/jem.74.4.309

3. CM Westhoff and Reid ME (2004). Review: the Kell, Duffy and Kiddd blood group systems.Immunohematology. 2004;20(1):37-49. PMID15373667. 